\title{
FISCAL POLICY AND EXPECTATIONS IN BRAZIL
}

\author{
Adonias Evaristo da Costa Filho *
}

\begin{abstract}
Resumo
Este artigo estuda os efeitos de notícias fiscais sobre a economia brasileira, baseando-se na nova literatura que procura identificar choques na política fiscal por meio de informações de previsões profissionais. É construída uma estrutura a termo de expectativas de superávit primário para o Brasil, e estimadas funções de reação para diferentes maturidades. As notícias fiscais são decompostas em um componente esperado e outro não esperado, baseados nos valores previstos e nos resíduos das funções de reação. Notícias fiscais esperadas e não esperadas são identificadas respectivamente como o primeiro fator das séries de valores previstos $\mathrm{e}$ dos resíduos das funções de reação, procurando capturar as notícias que tendem a persistir no horizonte de previsão. Embora com substancial incerteza, notícias sobre um aperto fiscal provocam um aumento de curto prazo no produto, uma queda da inflação, um declínio do salário real e uma depreciação da taxa de câmbio real.
\end{abstract}

Palavras-chave: política fiscal; superávit primário; notícias; expectativas.

\begin{abstract}
This paper studies the effects of fiscal news on the Brazilian economy, building on the new literature that seeks to identify fiscal policy shocks through information from professional forecasts. I build a term structure of primary balance expectations in Brazil, and estimate fiscal reaction functions for different maturities. Primary balance forecasts are decomposed into an expected and unexpected component, based on predicted and residuals obtained from the reaction functions. Expected and unexpected fiscal news are identified respectively as the first factor of the predicted and residual series from the reaction functions, aiming to capture the news that are likely to persist over the forecast horizon. Although with substantial uncertainty, fiscal tightening news induce a short-lived increase in growth, fall in inflation, decline in the real wage and a depreciation of the real exchange rate.
\end{abstract}

Keywords: fiscal policy; primary balance; news; expectations.

JEL classification: E62, H3.

DOI: http://dx.doi.org/10.11606/1980-5330/ea128459

\footnotetext{
* Doutor em Economia, Universidade de Brasília. Funcionário do Tesouro Nacional e Professor do IDP. E-mail: adoniasevaristo@hotmail.com. Disclaimer: As opiniões expressas neste trabalho são de exclusiva responsabilidade do autor, não expressando necessariamente a opinião da Secretaria do Tesouro Nacional. Portaria STN 833, de 28 de novembro de 2018.
} 


\section{Introduction}

This paper investigates the effects of news about fiscal policy on the Brazilian economy, aiming to take into account the role of expectations in the analysis of the effects of fiscal policy on output.

Since the global financial crisis of 2007-2008, there has been a renewed interest on the effects of fiscal policy, particularly in countries where policy interest rates were limited by the zero lower bound on nominal interest rates, limiting the ability to stimulate the economy through monetary policy.

Although that was far from being the case of Brazil, the 2014-2016 recession, one of the deepest in the history of the country, sparked a lively debate about the effects of fiscal policy. On the one hand, many commentators have argued that uncertainty about debt sustainability was one of the main causes of the recession, since government spending was growing faster than revenues for a long time. On the other hand, others argue that the spending cuts contributed significantly to the depth of the recession. Underlying this argument is the assumption that fiscal multipliers are larger in recessions.

Identification of the effects of fiscal policy is complicated by the presence of potentially large implementation lags and uncertainties arising from pending parliament approvals. The role of antecipation and fiscal foresight in fiscal policy has been emphasized, among others, by Mertens \& Ravn (2010), Ramey (2011), Mertens \& Ravn (2012), Leeper et al. (2012), and Leeper et al. (2013). Fiscal foresight essentially simplifies to the fact that, with antecipation, the information set of the econometrician is smaller than that of private agents, hindering the ability to properly identify the effects of fiscal policy shocks if not taken into account.

One of the main strategies to identify fiscal policy shocks is the narrative approach, which is based on historical records of tax and spending measures (Romer \& Romer 2010, Ramey 2011). A second approach is the military dummies approach, which relies on major military buildups, thus capturing exogenous spending shocks (Ramey \& Shapiro 1998, Ramey 2011). A third approach, that overlooks the role of expectations and the time elapsed between announcement and implementation, is to use the realized spending and taxes series in the econometric analysis, typically through a vector autoregression (VAR) as in Blanchard \& Perotti (2002), assuming that government spending does not respond contemporaneously to output.

Ramey (2011) constructed a measure of present value of government spending for the United States based on Business Week articles. With this variable, the effects of spending shocks on GDP are found to be smaller than one, and associated with a negligible effect on private consumption and a decline in real wages, therefore consistent with the neoclassical model. She also investigates the effects of government spending shocks using the forecast revisions of federal spending based on the Survey of Professional Forecasters (SPF), finding negative effects on GDP and consumption.

On the other hand, Perotti (2011) disputes the results obtained by Ramey (2011), arguing that they are not robust to different specifications of her defense news dummy and to different samples. He concludes that the government spending multiplier is likely to be close to one, along with positive responses of private consumption and real wage. Moreover, he argues that results from SVARs and EVARs are likely to be small, thus downplaying the importance of fiscal foresight. 
For Germany, Gründler \& Sauerhammer (2018) built a dummy variable of large increases in government spending based on historical issues of Der Spiegel magazine, replicating one of the methodologies employed by Ramey (2011). They find that government spending shocks crowd out private sector in Germany, leading to a fall in GDP, while failing to take into account the role of expectations induces a positive effect of government spending on GDP.

Along with the efforts to create variables that capture antecipation effects of fiscal policy based on historical reports from the media, a new strand of the literature of news and fiscal policy has relied on forecasts to identify fiscal policy shocks. Ramey (2011) uses the forecast error of government spending, with forecasts obtained from the SPF, in a VAR. The forecast error encompasses both the forecast error for the current quarter ("nowcast error"), and forecast revisions for future quarters.

Perotti (2011) decomposes the forecast error of government spending growth rate in a current period (time $t$ ) surprise and forecasts revisions between the previous and the current period, casting double in the usefulness of these measures to forecast future government spending.

Ricco (2015) distinguishes between nowcast forecast errors, that is, the forecast error for government spending in the current period, and forecast revisions of government spending in the future. The nowcast errors are denominated "misexpected" shocks, being essentially the surprise component of current government spending, while forecast revisions are associated with the news shocks. The news shocks are further decomposed in changes in expectatations for government spending in the current period ("unexpected fiscal changes") and in future quarters ("expected fiscal changes"). He uses individual forecasts from the SPF to study the effects of these shocks, finding that fiscal news related to forecast revisions are expansionary, while the nowcast error shock seems to be contractionary.

Forni \& Gambetti (2016) use two measures from the SPF to identify the shocks: i) the expectation of future spending growth for the following four quarters and ii) the forecast revision for government spending for a given horizon from the current period relative to the previous period. These variables are intended to capture the news about fiscal policy. They then include these variables in open economy VARs, in addition to the government spending variable, thus differentiating between "surprise shock", the one associated with the government spending, and the "news shock", the one related to information from forecasts.

This research builds a new measure of fiscal policy shocks following the recent literature, that has emphasized the role of news and anticipation effects in fiscal policy. Hence, the main contribution is to take into account the role of expectations in the analysis of fiscal policy shocks for the Brazilian economy, and also to extend the available evidence to a large emerging country, since overall the empirical findings point to lower effects of fiscal policy when antecipation is considered. The low military involvement of Brazil and potential pitfalls of the narrative approach reduces the appeal of other strategies to identify fiscal policy shocks in the country.

The paper is organized as follows. Section 2 is devoted to the construction of a term structure of primary balance expectations for Brazil. Section 3 presents the measure of fiscal policy news. Section 4 proceeds with an analysis of the effects of fiscal policy news in Brazil. Section 5 investigates how fiscal news affect confidence and Section 6 concludes. 


\section{The Term Structure of Primary Balance Expections}

The FOCUS survey, conducted by the Central Bank of Brazil, collects forecasts of many macroeconomic indicators from more than a 100 professional forecasters on a daily basis. The survey includes forecasts for the following fiscal variables: primary balance, nominal deficit, and the net public debt, all in percentage of GDP. For the purposes of this paper, the interest lies mainly on forecasts for the primary balance, the instrument for fiscal policy in Brazil. I also collected forecasts for GDP growth and consumer prices inflation (IPCA), since these variables will be used in the derivations of the fiscal news measure in Section 2. All forecasts collected were median values.

Since forecasts are available on a daily basis for a given year, the end of year forecasts were transformed on constant maturity forecasts. For each date in which the forecasts were available, forecasts for up to the longest year available were collected. Forecasts for a given year are then transformed in a constant maturity series, by means of the following equation:

$$
\begin{aligned}
& \text { forecast }_{j+1}\left(\text { month }_{i} \text { year }_{j}\right)= \\
= & \left(\frac{12-\text { month }(\text { date })}{12}\right) * \text { forecast }_{\left(\text {year }_{j}\right)+} \\
+ & \left(\frac{\text { month }(\text { date })}{12}\right) * \operatorname{forecast}_{\left(\text {year }_{j+1}\right)}
\end{aligned}
$$

Where $j=0,1,2$ for forecasts for the primary balance, GDP growth and consumer price inflation. This formula builds the constant maturity forecast as a weighted average of the forecasts of two subsequent years. For a given date, I have forecasts for up to 4 years ahead for the growth and inflation projections. The equation is used for each pair of subsequent years to create the constant maturity forecasts for 1, 2 and 3 years ahead.

Each point in time can be thought of as a "term structure" of expectations for the primary balance, GDP growth and inflation. The constant maturity expectations series are shown in Figure 1, beginning in the first quarter of 2002 and ending in the fourth quarter of 2016. The quarterly figures correspond to the average of daily constant maturity forecasts constructed with median values collected from the survey.

\section{A Measure of Fiscal News}

The measure of fiscal news borrows from the literature on monetary policy shocks, specifically from Romer \& Romer (2004). Fiscal policy news intend to capture the fraction of primary balance expectations that is unrelated to the forecasts for GDP growth, inflation, and net debt, along with their revisions. Therefore, the fiscal news series express only the expected evolution of fiscal policy, absent influences from the state of the economy. This is somehow different from the papers that use forecast revisions to identify fiscal news, since revisions may also simply reflect the state of the economy in the future, and not necessarily the expected path of discretionary fiscal policy. 

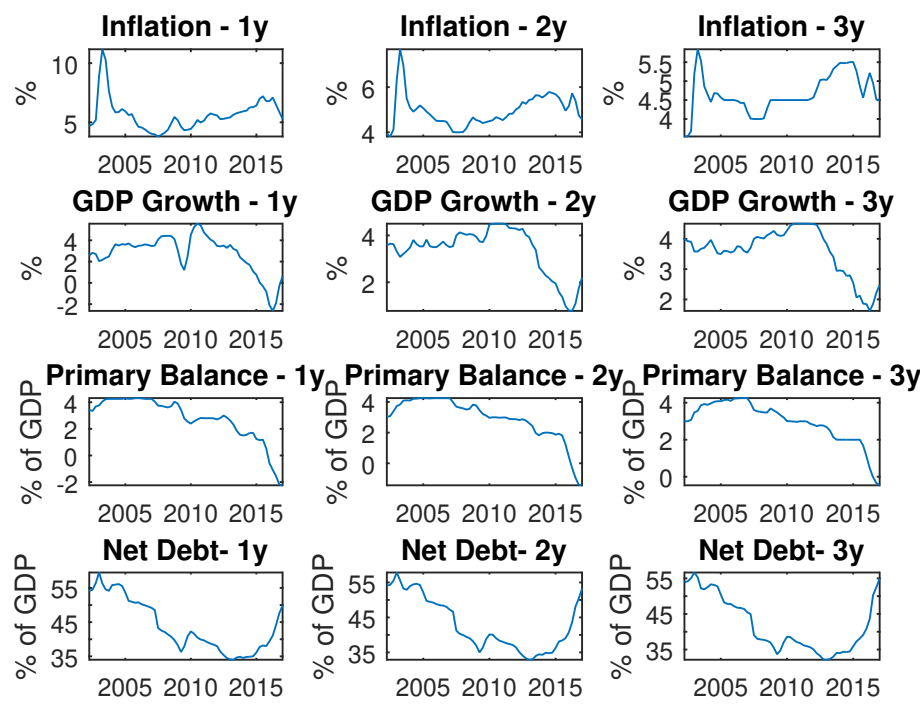

Note: $1 \mathrm{y}, 2 \mathrm{y}$ and $3 \mathrm{y}$ refer to, respectively, 1 year ahead, 2 years ahead and 3 years ahead.

Figure 1: Constant maturity expectations

Romer \& Romer (2004) ran the following regression:

$$
\begin{aligned}
\Delta f f_{m}=\alpha & +\beta f f b_{m}+\sum_{i=-1}^{2} \gamma_{i} \Delta \tilde{y}_{m i}+\sum_{i=-1}^{2} \lambda_{i}\left(\Delta \tilde{y}_{m i}-\Delta \tilde{y}_{m i-1, i}\right) \\
& +\sum_{i=-1}^{2} \varphi_{i} \tilde{\pi}_{m i}+\sum_{i=-1}^{2} \theta_{i}\left(\tilde{\pi}_{m i}-\tilde{\pi}_{m i-1, i}\right)+\rho \tilde{u}_{m 0}+\varepsilon_{m}
\end{aligned}
$$

Where $\Delta f f_{m}$ is the change in the funds rate at meeting $m, f f b_{m}$ is the level of the funds rate before any changes associated with meeting $m$, included to capture any mean reversion behavior from the Federal Open Market Committee (FOMC) of the Federal Reserve (FED), and $\tilde{\pi}, \tilde{y}$ and $\tilde{u}$ refer to the forecasts of inflation, real output growth and unemployment rate. Finally, the $i$ transcript refers to the horizon of the forecast: -1 is the previous quarter; 0 is the current quarter; and 1 and 2 are one and two quarters ahead.

Romer \& Romer (2004) use data from the Greenbooks, and then proceed in their analysis identifying the residuals from the estimated equation as a measure of monetary policy shocks, i.e., changes in the funds rate that could not the accounted for by information of future economic conditions, which were available for the FOMC at the time of the meetings. This measure of shock can be interpreted as the portion of interest rate changes that is not due to the current and projected state of the economy.

The measure of fiscal news builds on the same equation as Romer \& Romer (2004), except that I replace the funds rate by the expectations for the primary balance, and augment it by expectations of the net debt. Furthermore, since there are no expectations for the unemployment rate in the FOCUS survey, I did not control for this variable in the regressions. Therefore, for each maturity, the forecasts of the primary balance are regressed on the forecast 
revisions of inflation, GDP growth and net debt, and their levels in a given quarter:

$$
\begin{aligned}
p b_{j, t}=\alpha+\beta_{0} \Delta \tilde{y}_{j, t}+\beta_{1}\left(\Delta \tilde{y}_{j, t}-\right. & \left.\Delta \tilde{y}_{j, t-1}\right)+\beta_{2} \tilde{\pi}_{j, t}+\beta_{3}\left(\tilde{\pi}_{j, t}-\tilde{\pi}_{j, t-1}\right)+ \\
& +\beta_{4} n e t \text { debt }_{j, t}+\beta_{5} \Delta n e t \text { debt }_{j, t}+\varepsilon_{t}
\end{aligned}
$$

Where $p b_{j, t}$ is the forecast for the primary balance $j=1,2,3$ years ahead; the difference operator $\Delta$ is the change in forecasts relative to the previous quarter; and the other variables are defined as before, i.e., $\tilde{\pi}$ and $\tilde{y}$ refer to the forecasts of inflation and real output growth.

This equation can be interpreted as the expected fiscal reaction function of the market, and is aimed to capture the endogenous evolution in the primary balance that is due to state of the economy and the average response of the primary balance to the public sector indebtness in Brazil. Thus, I label the predicted variable from this regression as a measure of anticipated or expected fiscal news. On the other hand, the residuals are the unexpected fiscal news, and convey the discretionary stance of fiscal policy, i.e., actions that cannot be justified by the state of the economy and the historical reaction to the indebtness of the public sector.

Results from this regression are presented in Table 1. While the effect of growth on the primary balance is immediate, the inclusion of inflation as a regressor can be justified by the Tanzi effect, whereby tax revenues are negatively affected by inflation.

Table 1 shows the expected fiscal reaction fuctions estimated based on Equation (3) by OLS, estimated from 2002Q2 to 2016Q4. Each column shows the regression for each maturity in the term structure of primary balance expectations. Overall, the results show that primary balance expectations depend positively on the expected GDP growth and the level of net debt for the same horizon, implying that forecasters expected that fiscal authorities would react by increasing the primary balance to offset an increase in the net debt. On the other hand, results show negative coefficients for the forecast revisions of GDP growth and net debt on the expected level of the primary balance, implying that forecasters were expecting that fiscal policy was not reacting accordingly as news of GDP growth and net debt arrived, indicating a lack of response of fiscal policy at the margin. The constant is negative, consistent with the declining expected primary balance over the estimated period. Finally, expected inflation levels are not a significant determinant of primary balance expectations in Brazil, since only the forecast revision for inflation 3 years ahead is significant in the regressions.

Overall, the models show a large explanatory power, with R2 ranging from 0.70 to 0.80 . I do not control for autocorrelation in the estimations because the goal is the remove the share of forecasts that is endogenous to the state of the economy and the historical behaviour of fiscal policy, since forecasters may revise fiscal policy expectations only due to different underlying assumptions for the evolution of the economy, regardless of the expected discretionary behaviour of fiscal policy.

Predicted values of the regressions 2 and 3 are shown in Figure 2 for each horizon of the term structure of expectations. The predicted variables are labeled "expected news", since it is the component of the expected primary balance that reflects the state of the economy. The residuals from regres- 
Table 1: Expected fiscal reaction functions

\begin{tabular}{|c|c|c|c|}
\hline \multirow{3}{*}{ Variables } & (1) & (2) & (3) \\
\hline & \multicolumn{3}{|c|}{ Expected Primary Balance } \\
\hline & 1 Year Ahead & 2 Years Ahead & 3 Years Ahead \\
\hline$\tilde{\pi}_{1, t}$ & $\begin{array}{r}-0.0032 \\
(0.076)\end{array}$ & & \\
\hline$\Delta \tilde{y}_{1, t}$ & $\begin{array}{l}0.6100^{* * * *} \\
(0.098)\end{array}$ & & \\
\hline net debt $t_{1, t}$ & $\begin{array}{c}0.1000^{* * * *} \\
(0.012)\end{array}$ & & \\
\hline$\tilde{\pi}_{1, t}-\tilde{\pi}_{1, t-1}$ & $\begin{array}{r}-0.1100 \\
(0.100)\end{array}$ & & \\
\hline$\Delta \tilde{y}_{1, t}-\Delta \tilde{y}_{1, t-1}$ & $\begin{array}{c}-0.9300^{* * * *} \\
(0.290)\end{array}$ & & \\
\hline$\Delta n e t d e b t_{1, t}$ & $\begin{array}{c}-0.1900^{* *} \\
(0.072)\end{array}$ & & \\
\hline$\tilde{\pi}_{2, t}$ & & $\begin{array}{r}-0.0910 \\
(0.100)\end{array}$ & \\
\hline$\Delta \tilde{y}_{2, t}$ & & $\begin{array}{l}0.8100^{* * *} \\
(0.110)\end{array}$ & \\
\hline net debt $2, t$ & & $\begin{array}{c}0.0810^{* * *} \\
(0.011)\end{array}$ & \\
\hline$\tilde{\pi}_{2, t}-\tilde{\pi}_{2, t-1}$ & & $\begin{array}{r}-0.2500 \\
(0.150)\end{array}$ & \\
\hline$\Delta \tilde{y}_{2, t}-\Delta \tilde{y}_{2, t-1}$ & & $\begin{array}{c}-2.2600^{* * * *} \\
(0.700)\end{array}$ & \\
\hline$\Delta n e t d e b t_{2, t}$ & & $\begin{array}{c}-0.3100^{* * *} \\
(0.074)\end{array}$ & \\
\hline$\tilde{\pi}_{3, t}$ & & & $\begin{array}{r}-0.1400 \\
(0.190)\end{array}$ \\
\hline$\Delta \tilde{y}_{3, t}$ & & & $\begin{array}{l}0.8200^{* * * *} \\
(0.150)\end{array}$ \\
\hline net debt $t_{3, t}$ & & & $\begin{array}{l}0.0570^{* * * *} \\
(0.0096)\end{array}$ \\
\hline$\tilde{\pi}_{3, t}-\tilde{\pi}_{3, t-1}$ & & & $\begin{array}{c}-0.4200^{*} \\
(0.220)\end{array}$ \\
\hline$\Delta \tilde{y}_{3, t}-\Delta \tilde{y}_{3, t-1}$ & & & $\begin{array}{l}-2.0100^{* * * *} \\
(0.730)\end{array}$ \\
\hline$\Delta n e t d_{e b} t_{3, t}$ & & & $\begin{array}{c}-0.2700^{* * * *} \\
(0.054)\end{array}$ \\
\hline Constant & $\begin{array}{c}-3.3200^{* * * *} \\
(0.650)\end{array}$ & $\begin{array}{c}-2.8900^{* * *} \\
(0.690)\end{array}$ & $\begin{array}{r}-1.7000 \\
(1.170)\end{array}$ \\
\hline Observations & 59 & 59 & 59 \\
\hline R-squared & 0.8030 & 0.7730 & 0.7080 \\
\hline
\end{tabular}

sions based on Equation (3) are shown in Figure 3, labeled as "unexpected news", and reflect the discretionary component of forecasts of fiscal policy variables that cannot be justified by the state of the economy and the historical behaviour of fiscal policy.

Expected news show that fiscal policy was basically stable from the end of 2002 until the global financial crisis in 2008, with primary balance expectations hovering around $4 \%$. During the global financial crisis, primary balance expectations fell to $2 \%$, affected by the decline in output growth at the time. After a recovery following the crisis, expected primary surplus began a downward trend, reaching basically $0 \%$ on average in the first quarters of 2016 . Since then, expectations have increased slightly, although remaining less than $2 \%$ for all horizons in the term structure of primary balance expectations.

Unexpected news, which aim to capture the discretionary component of fiscal policy, show that fiscal policy was basically neutral from the end of 2002 until the global financial crisis, with primary balance expectations evol- 


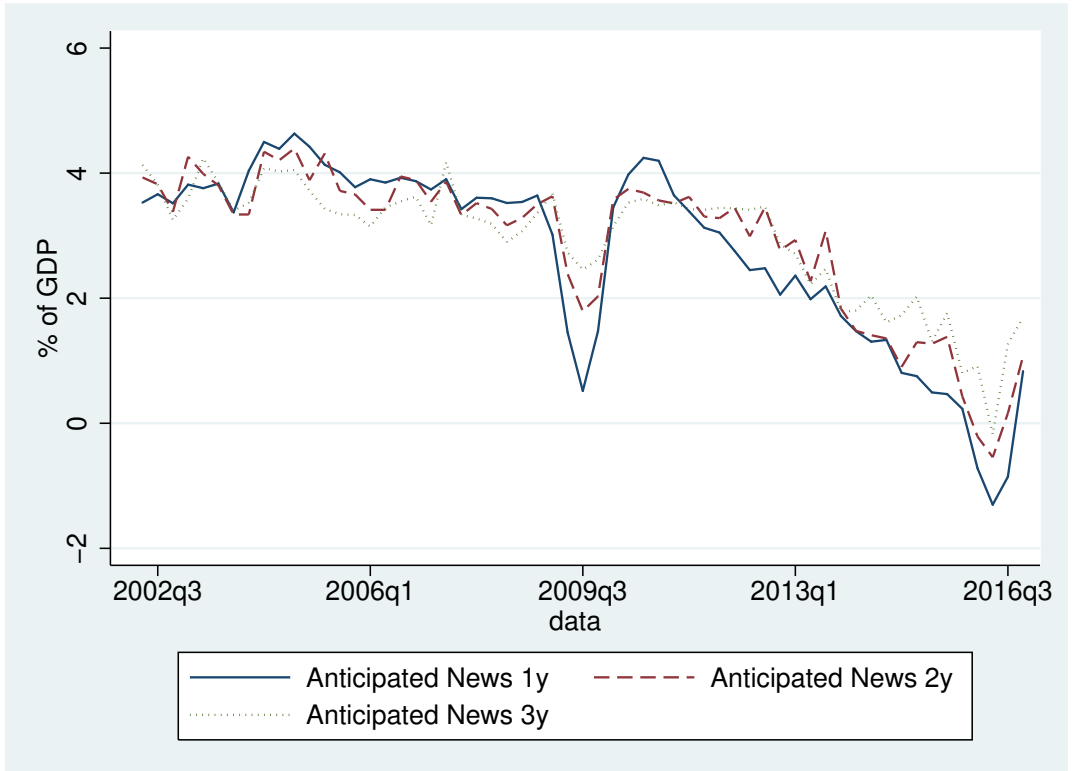

Figure 2: Expected news

ving almost one for one with the state of the economy. The global financial crisis episode marked a sharp reversal of fiscal policy, shifting from a contractionary stance of more than $1 \%$ of GDP in 2009 Q3 to an expansion of $1 \%$, on average, from 2010Q1 to 2011Q2. The period from 2011Q3 to 2013Q4 fiscal policy stance was expansionary, but on average less than in the aftermath of the global financial crisis. Fiscal policy shifted to a contractionary stance from 2013Q4 to 2015Q2, and reverted to a deeply expansionary phase from 2015Q3 onwards.

In order to capture the common dynamics of the expected and unexpected fiscal news, I extract the first factor of each of these groups of series for the different maturities. This was done because the interest of this research lies in the common variability of each series, there is, fiscal news that are perceived by analysts as permanent, and therefore do not reflect temporary or one-off episodes. Since the first factor has the interpretation of the level of yield curve in finance models, I interpret them as the level of the term structure of primary balance expectations. Figure 4 plots both series, and show that they retain the common variability observed in the previous figures.

\section{The Impact of Fiscal News Shocks}

In the ongoing research agenda on the role of expectations in fiscal policy, VARs models that take into account forward-looking variables have been labeled EVARs. The measure of fiscal policy shocks proposed here is forward looking by construction, since it captures the fraction of the expected primary surplus balance that is orthogonal to changes in expectations for growth, inflation and net debt for the same horizon, so as to take into account only news about the expected fiscal policy stance. It then excludes the endogenous component of fiscal policy. Both measures of fiscal news, expected and unexpected, are included in VAR models. 


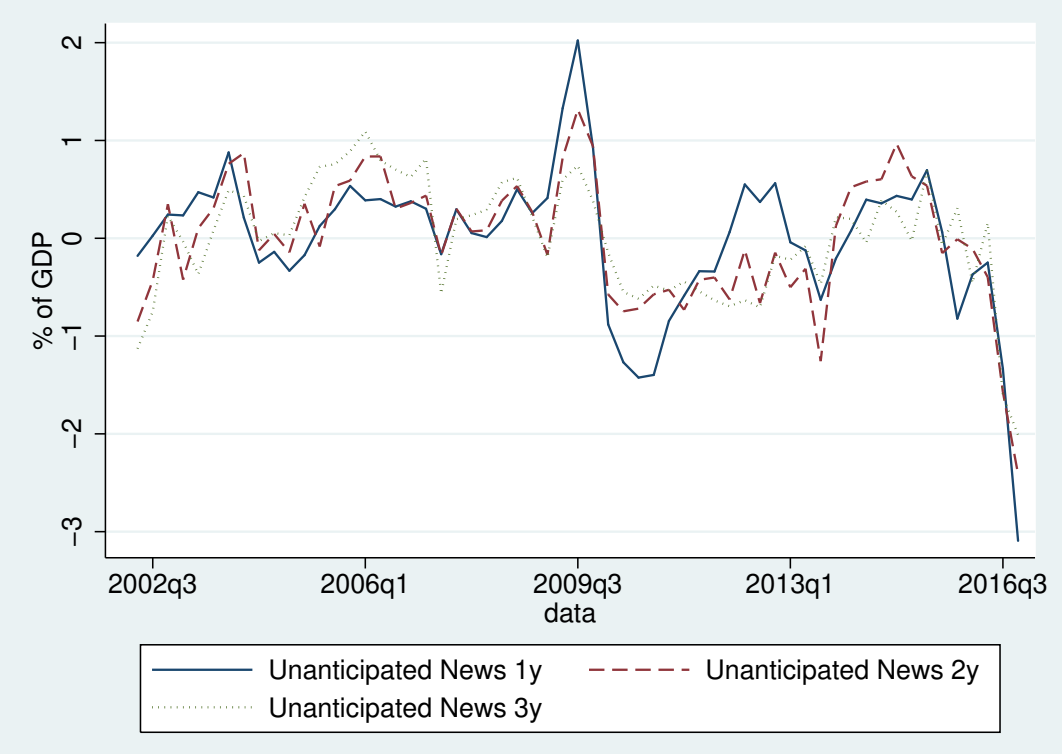

Figure 3: Unexpected news

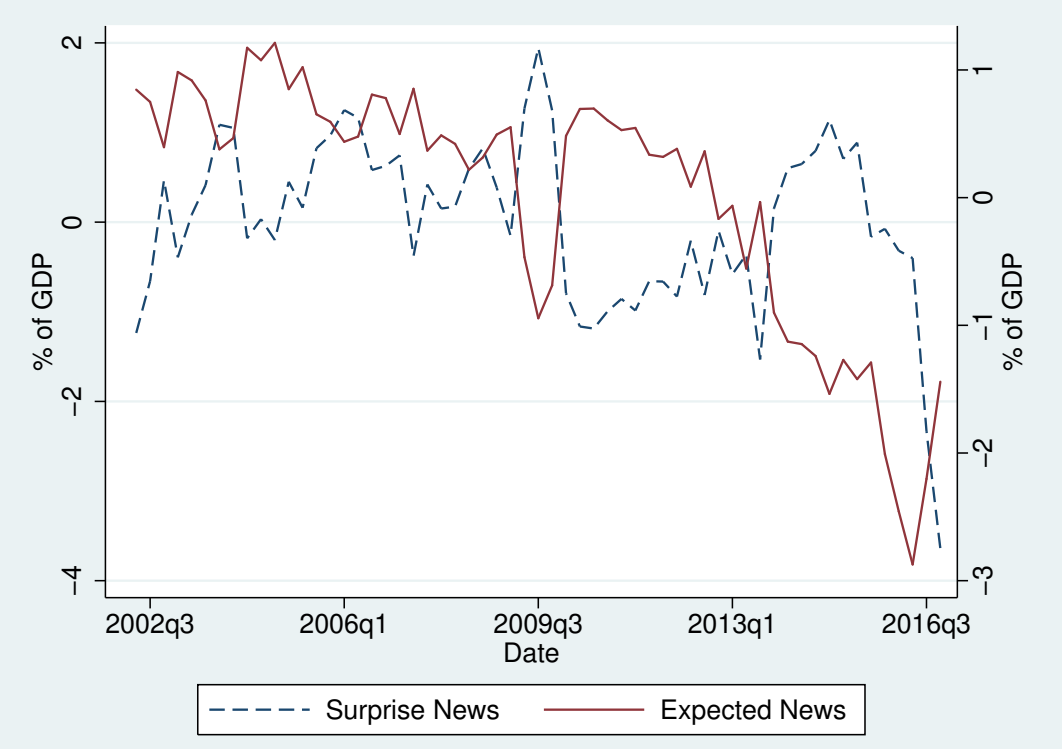

Figure 4: Expected and unexpected news 
In order to assess the impact of fiscal news, I estimated two VARs under the standard Cholesky identification scheme, using the following order: expected or unexpected fiscal news as presented before, first difference of the log of deseasonalized real GDP, quarterly market prices inflation of the IPCA (official price index), log of the real wage from the metropolitan region of São Paulo (source: SEADE) and the log of the real exchange rate from the Central Bank of Brazil ${ }^{1}$. This implies that unexpected fiscal news affect the other variables contemporaneously, while it is only affected by them with a lag of one quarter. Sample period ranges from 2002Q1 to 2016Q4, comprising 60 observations. Data used in the estimations are shown in Figure 5. It is also presented the consumer confidence index and expectations index com Fecomércio SP, which will be used in the next section.

The model can be written in its reduced form as:

$$
Y_{t}=A(L) Y_{t-1}+U_{t}
$$

Where $U_{t}$ is the vector of reduced form residuals, which are expressed as a linear combination of the strucutral errors $V_{t}$, where $\Gamma$ is a lower triangular matrix:

$$
U_{t}=\Gamma V_{t}
$$

Information criteria pointed to 2 lags in the system ${ }^{2}$. The appendix shows that all eigenvalues lied inside the unit circle, so that the estimated models are stable.

Figure 6 shows the baseline responses of GDP growth to an expected and unexpected fiscal news shock. Unexpected fiscal news about tightening in fiscal policy, represented by one standard deviation increase in the primary balance, induce an increase in GDP growth of $0.15 \%$ on impact, consistent with news about austerity being expansionary, but after the first quarter, GDP growth turns negative between 2 and 4 quarters after the shock. The shock is dissipated after 5 quarters. On the other hand, expected news about tightening in fiscal policy lead to an increase in output growth of around $0.2 \%$, and fades after 5 quarters. Thus, responses to expected news are consistent with news about austerity being expansionary, while the response to unexpected fiscal tightening news is more ambiguous.

Figure 7 presents the impulse responses of fiscal news shocks on output growth and inflation, along with $95 \%$ confidence intervals. The $95 \%$ confidence intervals of the responses of real GDP are large and include zero, so it is unclear the output effects of news about fiscal consolidation. Unexpected fiscal tightening news initially have a positive impact on GDP and then turn negative. In Appendix Appendix A, I report that the impulse response at $68 \%$ level shows a positive and statistically significant response of GDP to an unexpected fiscal tightening news. The cumulative fiscal tightening news

\footnotetext{
${ }^{1}$ For the real wage and the real exchange rate, I first take the quarterly average of the original series on a monthly frequency before applying the log. The national labor market survey (PME) was discontinued in early 2016. For this reason, I use the real wage from SEADE instead of the one from the national statistics office (IBGE), since the estimation period goes until the end of 2016.

${ }^{2}$ The Lagrange Multiplier p-value at this lag is 0.65 and 0.24 , respectively, in case of the VARs including the unexpected and expected fiscal news. Hence, it fails to reject the hypothesis of no autocorrelation in the residuals.
} 

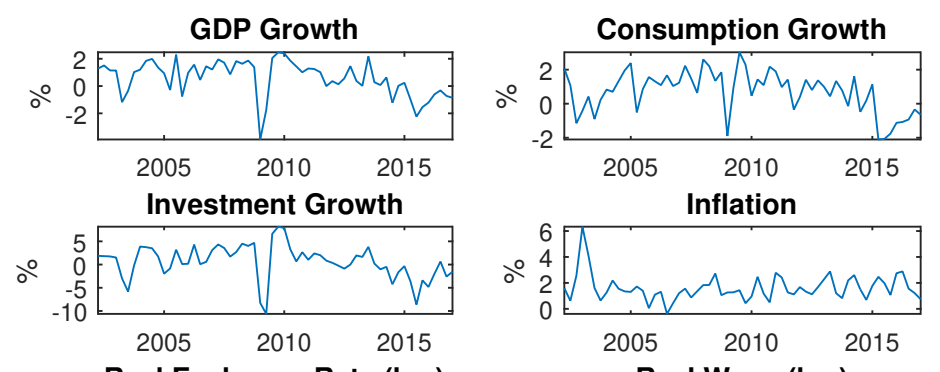

Real Exchange Rate (log)
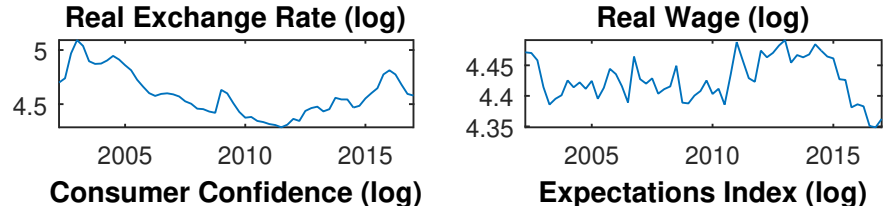

Expectations Index (log)
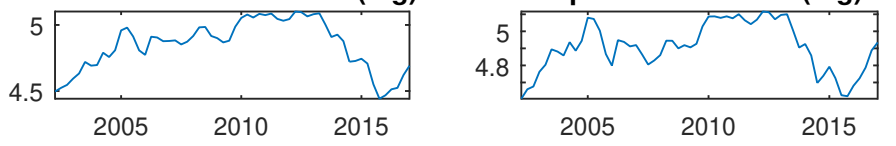

Figure 5: Data

multiplier is positive, at $0.19^{3}$. Expected fiscal news have positive effects on GDP growth, being statistically significant. Inflation falls after news of a fiscal tightening, both expected and unexpected. In the former case, the response is more front loaded, while in the latter inflation falls only after some quarters after news arrived.

The forecast error variance decomposition, presented in Table 2, shows that after 20 quarters, the real exchange rate, real wage and inflation are more significant than the unexpected fiscal news shock to explain the variability of real GDP. At this horizon, 73\% of the variance of GDP growth is due to its own shocks, $8 \%$ is due to shocks in the real exchange rate, $7 \%$ due to shocks in the real wage, and only $4 \%$ is explained by fiscal news shocks in the VAR system. Along the same lines, in the VAR that includes expected news variable, the variance decomposition after 20 quarters shows that $69 \%$ of the variance of real GDP is explained by its own shocks, $8 \%$ by shocks in the real exchange rate, $8 \%$ by fiscal news shocks, and only $5 \%$ by inflation shocks. These results suggest a limited role of discretionary fiscal news shocks in explaining real GDP growth in Brazil. As for systematic fiscal news, results show that expected news are more important than inflation shocks in the second model, comparable to real exchange rate and real wage shocks after 20 quarters.

The historical decomposition of the model is shown in the appendix. Except for 2016Q2, the contribution of unexpected fiscal news has been negative for GDP growth since 2014Q2 in the estimated model, although fiscal news indicate an expasionary stance since 2015Q3.

Figure 8 presents the impulse response functions of the real wage and the real exchange rate. Fiscal news depreciate the real exchange rate under the baseline. As for the real wage, unexpected fiscal news, represented by an

\footnotetext{
${ }^{3}$ Defined as the sum of the responses of GDP growth relative to the sum of the responses of fiscal tightening news after an orthogonalized shock.
} 


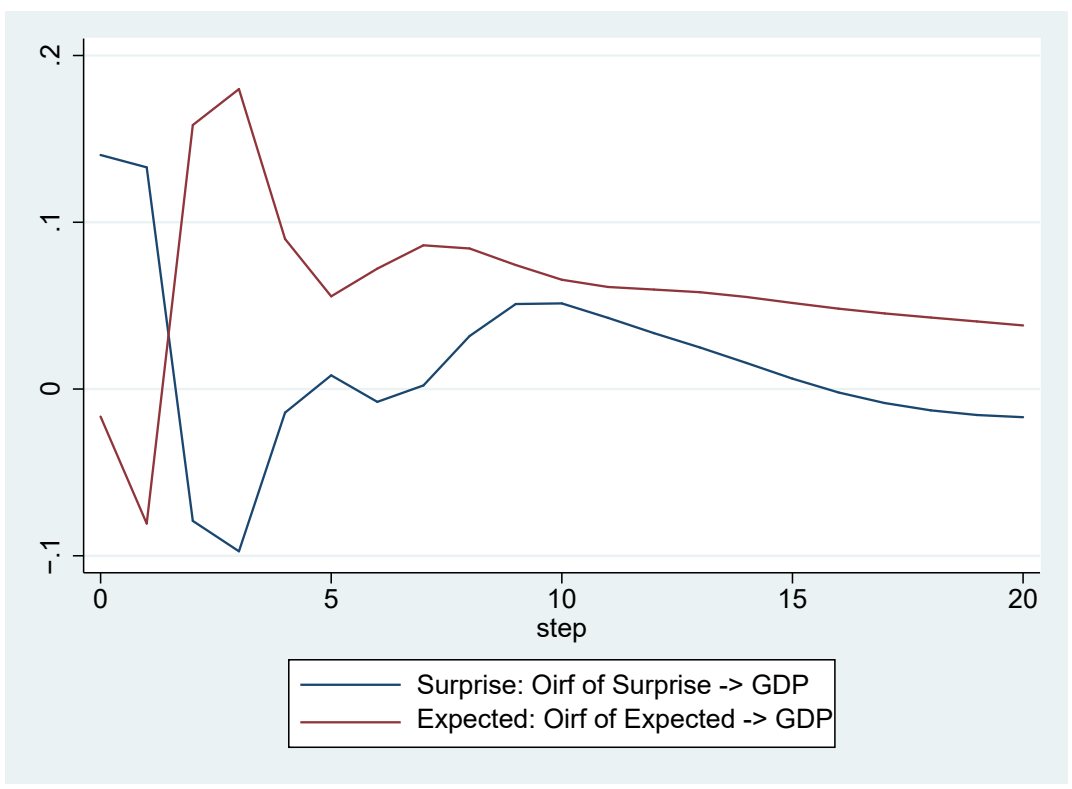

Figure 6: Baseline responses of GDP to fiscal news shock

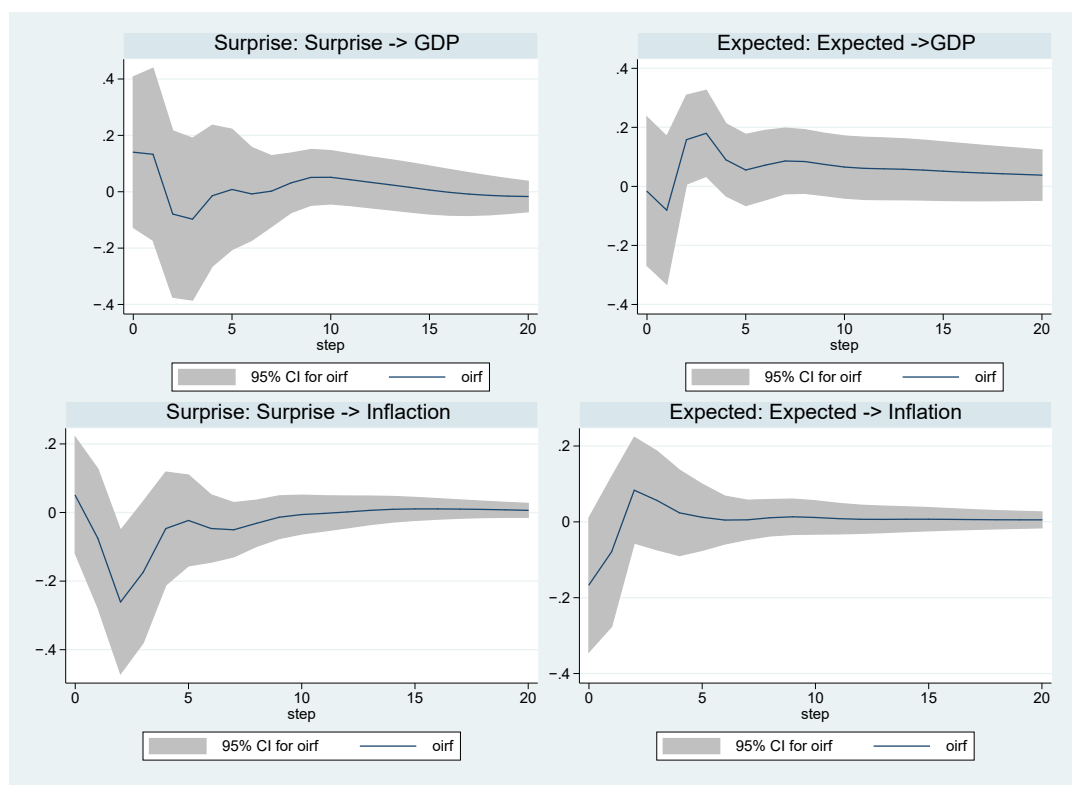

Figure 7: Response of GDP and inflation to fiscal news shocks 


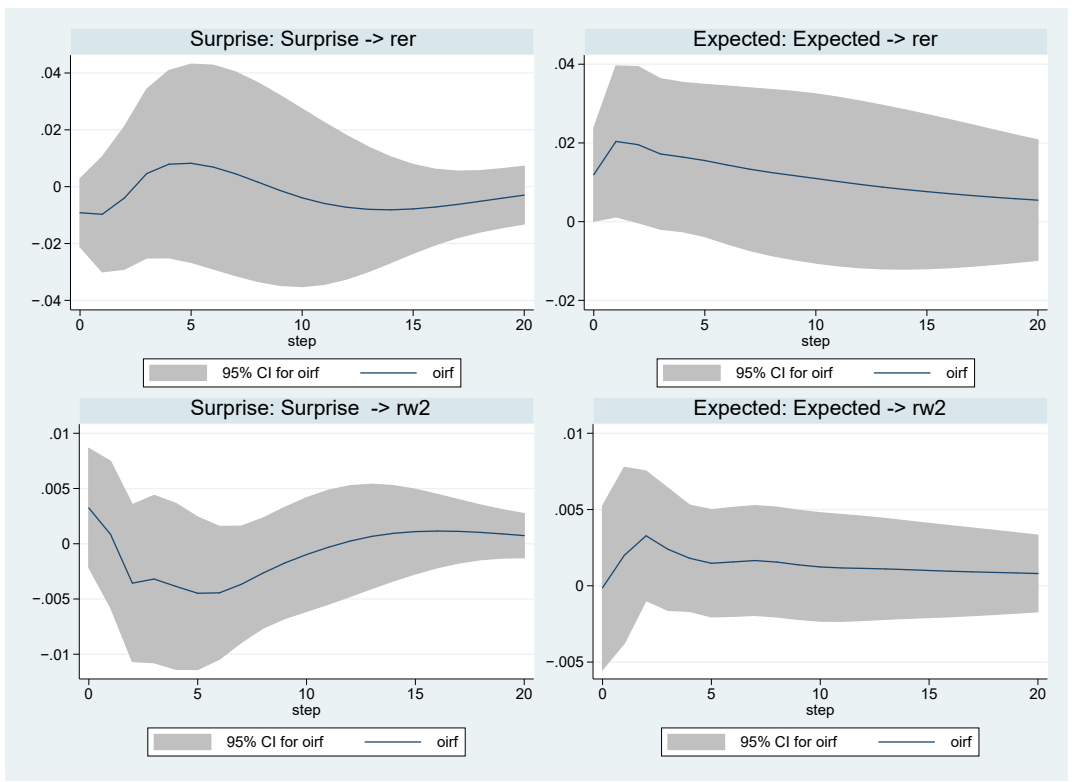

Figure 8: Response of the real wage and the real exchange rate to fiscal news shocks

Table 2: Forecast error variance decomposition of real GDP growth

\begin{tabular}{lccccc}
\hline \multirow{2}{*}{ Quarters } & \multicolumn{5}{c}{ Share Due To Each Shock } \\
\cline { 2 - 6 } & Surprise News & GDP Growth & Inflation & Real Wage & RER \\
\hline$h=5$ & $3.50 \%$ & $80.03 \%$ & $7.80 \%$ & $2.71 \%$ & $5.97 \%$ \\
$h=10$ & $3.52 \%$ & $75.45 \%$ & $8.31 \%$ & $5.34 \%$ & $7.39 \%$ \\
$h=15$ & $3.81 \%$ & $73.53 \%$ & $8.29 \%$ & $6.26 \%$ & $8.11 \%$ \\
$h=20$ & $3.80 \%$ & $72.82 \%$ & $8.29 \%$ & $6.90 \%$ & $8.19 \%$ \\
\hline \multirow{2}{*}{ Quarters } & \multicolumn{5}{c}{ Share Due To Each Shock } \\
\cline { 2 - 6 } & Expected News & GDP Growth & Inflation & Real Wage & RER \\
\hline$h=5$ & $5.60 \%$ & $79.63 \%$ & $5.06 \%$ & $3.10 \%$ & $6.61 \%$ \\
$h=10$ & $6.81 \%$ & $73.37 \%$ & $5.40 \%$ & $8.33 \%$ & $6.08 \%$ \\
$h=15$ & $7.70 \%$ & $70.65 \%$ & $5.24 \%$ & $9.29 \%$ & $7.12 \%$ \\
$h=20$ & $8.23 \%$ & $69.32 \%$ & $5.17 \%$ & $9.15 \%$ & $8.13 \%$ \\
\hline
\end{tabular}


increase in the expected primary balance, exert a negative effect on the real wage. On the other hand, an expected fiscal tightening leads to an increase in the real wage. The real wage is key to identify the effects of fiscal policy shocks (Eichenbaum et al. 1998). According to the neoclassical model, fiscal stimulus induces an increase in the labor supply through a wealth effect, increasing hours and decreasing the real wage. In the Keynesian model, fiscal stimulus shifts the demand of labor to the right, with an associated increase in real wage and hours.

Figure 9 shows the impulse response functions for the impact of fiscal news shocks on consumption and investment, along with GDP. These were obtained with the estimation of 4 additional VARs models, with the same specification and order as before, but replacing GDP each time by consumption or investment growth. Each model was estimated with 2 or 3 lags, which were enough to remove autocorrelation from the residuals. After a surprise fiscal news shock, consumption, investment and GDP fall, although on impact GDP grows led by investment. The $95 \%$ confidence intervals show sizeable uncertainty about the effects of the shock, with the response not being unambiguously negative following the shock. After an expected fiscal news shock, consumption, investment and GDP growth increases, consistent with news about austerity being expansionary. Unlike the case of surprise news, the impulse response in this case is statistically significant, since confidence intervals remain above zero after the shock.

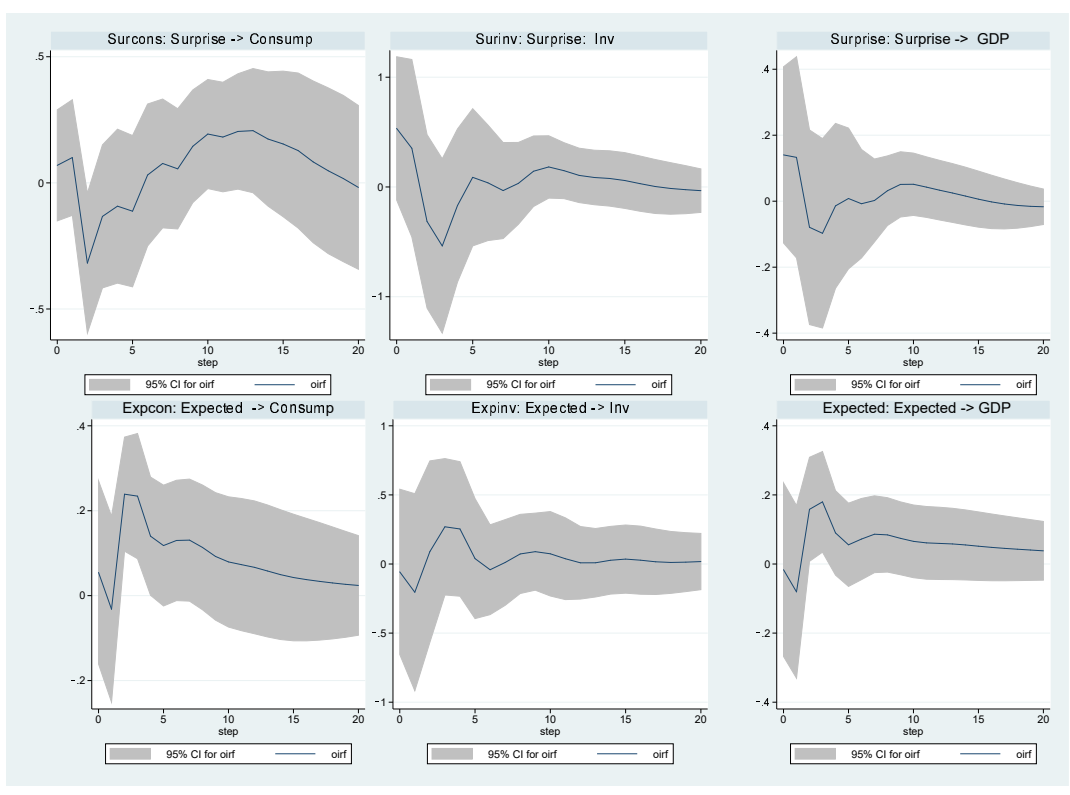

Figure 9: Response of consumption, investment and GDP to fiscal news shocks

\subsection{Comparison with Previous Results}

Available studies about the effects of fiscal policy in Brazil have largely neglected the role of expectations, building mainly on variations of the Blanchard \& Perotti (2002) approach, although recent studies have focused on cal- 
ibrated or estimated DSGE models ${ }^{4}$. Overall, the evidence points to low levels (below unity) of fiscal multipliers, and in some cases even non-Keynesian effects.

Peres \& Ellery Junior (2009) employ a structural VAR between central government spending, taxes and output to assess the effects of fiscal policy shocks between 1994 and 2005. They find Keynesian effects, although way below unit, in the response of output to fiscal shocks. The contemporaneous government spending multiplier is estimated at 0.4 , while the taxes multiplier is estimated at -0.2 .

Mendonça et al. (2009), using sign restrictions, find non Keynesian effects for fiscal policy in Brazil, with GDP falling with $77 \%$ probability after a government spending shock. On the other hand, after a tax shock, the authors find that GDP falls with a probability of $56 \%$.

Cavalcanti \& Silva (2010) investigate the effects of fiscal policy in Brazil for the period between 1995 and 2008. Taking into account the role of public debt, they find that fiscal multipliers were likely overestimated compared to models that do not include public debt, which they associate to debt sustainability concerns during those years. The authors test whether the structural shocks from their estimated VARs are predicted by many lagged variables, finding little evidence of predictability, suggesting that fiscal foresight was not an issue during the analyzed period.

Oreng (2012) studies the impact of fiscal policy in Brazil for the period of 2004-2011. He finds that multipliers over the analyzed period were close to one, with spending multipliers larger than taxes. The findings were based on VAR models considering fiscal balance (or spending or taxes, depending on the specification), output, inflation and real interest rate as endogenous variables under the standard Choleski identification scheme. The effects of an expansionary fiscal policy tend to be offset by an increase in inflation expectations accompanied by interest rate hikes.

Pires (2014) studies how fiscal multipliers vary over the business cycle in Brazil for the period between 1996 and 2012. He finds that the investment multiplier is consistently larger than one across different regimes, while tax multipliers are found to be negative, and government spending multipliers are non-significant.

\footnotetext{
${ }^{4}$ Among the studies based on the DSGE methodology, Carvalho \& Valli (2011) introduce a primary balance rule, public capital, non-Ricardian agents and transfers to the worse-off in an open-economy setting. They find that fiscal policy is inflationary, although it did not play a major role in the evolution of inflation over the period under the inflation targeting regime, even after the shift to expansionary policies following the global financial crisis. A reduction of the primary balance leads to a short-lived increase in output in their model. Carvalho et al. (2013) employ a mixed approach between DSGE and VAR models. First, they extract theoretical restrictions from a standard DSGE model, and in a second step they use VAR models with sign restrictions. They find that fiscal policy shocks in Brazil are consistent with features of the New Keynesian model. Costa Junior et al. (2016) estimate an open economy model to analyze the effects of expenditure and revenue-based fiscal policy on the Brazilian economy after 2008. They found tiny multipliers for the consumption tax and government spending, explaining why tax exemptions on durable goods after the crisis failed to stimulate the economy in a subtantial way. Moura (2015) finds larger and persistent multipliers for investments in infrastructure in Brazil relative to government consumption, using and open economy DSGE model. The results support measures of fiscal consolidation that preserve government investments relative to consumption. Finally, Cavalcanti \& Vereda (2015) simulate a large open economy with many fiscal policy features and study the effects of social transfers and public investment and employment under different fiscal rules.
} 
Matheson \& Pereira (2016) study fiscal multipliers in Brazil for the period 1999-2014, also with the VAR methodology. They find government spending and revenue multipliers around 0.5 , with government spending and public credit declining from levels above one since the global financial crisis, while the revenue multiplier has remained stable over time.

Mendonça et al. (2016) employ a myriad of identification strategies within the VAR framework to investigate the impact of output to fiscal policy in Brazil, also finding low (around 0.5), but positive multipliers.

There is no direct way to compare the results obtained previously in the literature with the ones obtained here, since the measure of fiscal shock in this paper is based on news about the primary balance, rather than government spending or taxes directly. Considering the positive fiscal tightening news multiplier, perhaps the most related finding in the literature is Mendonça et al. (2009).

\section{Fiscal News and Confidence}

Since Bachmann \& Sims (2012), there has been a growing interest in the role of confidence in the transmission of fiscal policy shocks. These authors find that confidence effects are more important in recessions, when government spending shocks signal future increases in productivity that influence confidence. Beetsma et al. (2015) analyze the role of confidence in fiscal consolidation episodes, finding negative response to fiscal consolidations announcements, with a greater (more negative) impact for revenues based relative to spending based fiscal consolidations. Furtuna et al. (2016) fail to find evidence of an increase in confidence after fiscal consolidation measures identified with the narrative approach.

In this section, it is investigated how confidence reacts to fiscal tightening news in Brazil. Following Bachmann \& Sims (2012) and Furtuna et al. (2016), I estimate a trivariate VAR with fiscal news ordered first, followed by the consumer confidence series from Fecomércio SP, or the expectations series from the same source, and quarterly output growth. These series were downloaded from IPEADATA.

The results from the estimated models are shown in Figure 10. After an unexpected fiscal tightening news, both consumer confidence and the expectations index decline under the baseline, although the responses are not statistically significant. If one considers the baseline, the results are consistent with empirical evidence found in Beetsma et al. (2015) and Furtuna et al. (2016). In the appendix, it is shown that confidence intervals at $68 \%$ point to a statistically significant negative response. On the other hand, expected tightening news that reflect the state of the economy and endogenous fiscal policy boost consumer confidence and expectations.

\section{Conclusion}

This paper dealt with antecipation effects of fiscal policy in Brazil, as identification in fiscal policy is complicated by fiscal foresight. Based on the recent literature strand that seeks to identify fiscal policy shocks from information from surveys (Ramey 2011, Ricco 2015, Forni \& Gambetti 2016) and the news shocks literature (Beaudry \& Portier 2014), I build a term structure of pri- 


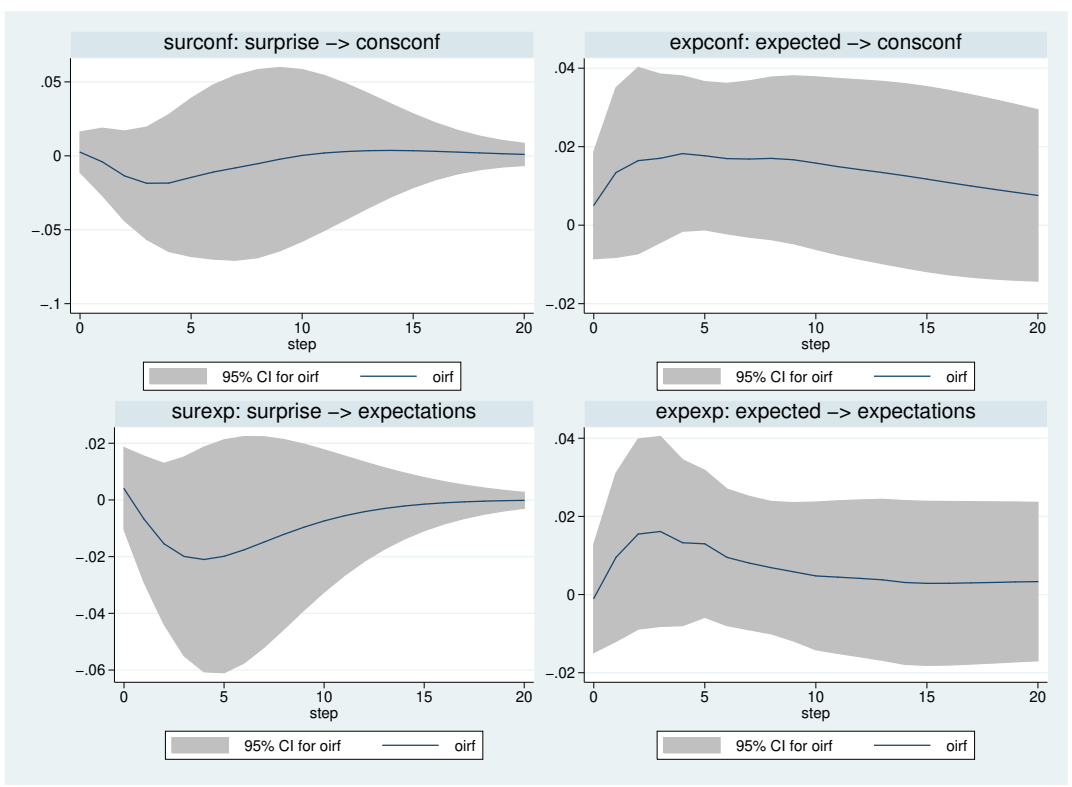

Figure 10: Response of consumer confidence and expectations to fiscal news shocks

mary balance expectations for Brazil. For each maturity of the term structure, I estimate an expected fiscal reaction fuction, with the primary balance as a function of levels and changes of GDP growth, inflation and net debt for each horizon.

Borrowing from the literature on monetary policy shocks, expected news about fiscal policy are identified as the first factor that drives the predicted primary balances for each horizon. Likewise, the first factor of the residuals of each reaction function is identified as the unexpected news, or the discretionary component of fiscal policy. Expected and unexpected news are, thus, identified as the "level" of the term structure of expected primary balances, since the interest lies in information that is likely to persist over time, rather than short-lived news represented by one-off episodes. The term structure is essentially forward looking, capturing the expected path of endogenous and discretionary fiscal policy.

Unexpected news about fiscal policy allows the identification of periods of fiscal expansion and contraction in Brazil, as perceived by forecasters. This series shows a neutral stance until the global financial crisis. This episode marked a shift in fiscal policy from a contractionary stance of almost $2 \%$ of GDP in 2009Q3 to an expansion of on average 1\% of GDP in the following quarters. The indicator of fiscal news shows an expansionary fiscal policy, although in varying degrees, from 2010Q1 to 2013Q3. From 2013Q4 to 2015Q2, fiscal policy turned to a contractionary phase, with a sharp reversal to expansion from 2015Q3 to 2016Q4, which marks the end of the sample.

By this characterization of phases of expansion and contraction in fiscal policy, at the onset of the recession that began in 2014Q2 fiscal policy stance was actually tight as perceived by forecasters, in the sense that the downward revisions in the primary balance from 2013Q4 to 2015Q2 could be fully explained by downward revisions in growth expectations. This evidence is 
at odds with the predominant view in the media that concerns about fiscal policy, particularly debt sustainability, were the primary cause of the recession. Along the same lines, primary balance forecasts for 2014 were hovering around $1 \%$ of GDP until a sharp deterioration took place in 2014Q4, as show in the appendix. Therefore, it took two quarters after the economy entered a recession for professional forecasters to consider a sharp deterioration in fiscal policy. A closer look at the evolution of forecasts for GDP growth and primary balance since 2013 leads to inconclusive results. While primary balance forecasts Granger cause GDP growth forecasts for 2013, no causality between these variables is found for 2014 and 2015, and both variables Granger cause each other for 2016. These results are presented in the appendix.

Having decomposed the term structure of expected primary balances into an expected and an unexpected component, I proceed in the analysis in order to investigate whether shocks in these series exert different impacts on the Brazilian economy. This was done through standard VAR models, as in much of the related literature, with the inclusion of the fiscal news series, output, real exchange rate, and the real wage. Additional models were also estimated replacing output by consumption and investment, in order to check for crowding out effects.

Expected and unexpected news were found to affect the economy differently. Expected news shocks are consistent with news about austerity being expansionary and "crowding in" effects, while unexpected fiscal tightening news have more unclear effects, with a tightening in fiscal policy associated with initially higher and subsequent lower output growth and real wages. Both shocks lead to lower inflation and devalued real exchange rates. The variance decomposition of real GDP growth of the estimated models shows a limited role for fiscal news as drivers of economic activity in Brazil, as compared to other variables. Another result is that expected fiscal news explain a larger share of GDP growth variance than unexpected news, which suggests that discretionary fiscal policy was not a main determinant of GDP growth in Brazil in the analyzed period.

This paper, therefore, contributes to the literature of news shocks in the context of fiscal policy for a large emerging market country, improving the knowledge of the channels of fiscal policy and effects of fiscal consolidation measures in Brazil.

\section{Bibliography}

Bachmann, R. \& Sims, E. R. (2012), 'Confidence and the transmission of government spending shocks', Journal of Monetary Economics 59(3), 235-249.

Beaudry, P. \& Portier, F. (2014), 'News-driven business cycles: insights and challenges', Journal of Economic Literature 52(4), 993-1074.

Beetsma, R., Cimadomo, J., Furtuna, O. \& Giuliodori, M. (2015), 'The confidence effects of fiscal consolidations', Economic Policy 30(83), 439-489.

Blanchard, O. \& Perotti, R. (2002), 'An empirical characterization of the dynamic effects of changes in government spending and taxes on output', The Quarterly Journal of Economics 117(4), 1329-1368. 
Cavalcanti, M. A. \& Vereda, L. (2015), 'Fiscal policy multipliers in a DSGE model for Brazil', Brazilian Review of Econometrics 35(2), 197-232.

Carvalho, D. B., Silva, M.E. A. \& Silva, I. É. M. (2013), 'Efeitos dos choques fiscais sobre o mercado de trabalho brasileiro', Revista Brasileira de Economia 67(2), 177-200.

Carvalho, F. A. \& Valli, M. (2011), Fiscal policy in Brazil through the lens of an estimated DSGE model. Working Paper Series 240, Central Bank of Brazil.

Cavalcanti, M. A. \& Silva, N. L. (2010), 'Dívida pública, política fiscal e nível de atividade: uma abordagem VAR para o Brasil no período 1995-2008', Economia Aplicada 14(4), 391-418.

Costa Junior, C. J., Cintado, A. C. G. \& Sampaio, A. V. (2016), 'Post-2008 Brazilian fiscal policy: an interpretation through the analysis of fiscal multipliers', Estudos Econômicos (São Paulo) 47(1), 93-124.

Eichenbaum, M., Fisher, J. D. et al. (1998), 'How does an increase in government purchases affect the economy?', Economic Perspectives-Federal Reserve Bank of Chicago 22, 29-43.

Forni, M. \& Gambetti, L. (2016), 'Government spending shocks in open economy VARs', Journal of International Economics 99, 68-84.

Furtuna, O., Beetsma, R. \& Giuliodori, M. (2016), Does the confidence fairy exist? Evidence from a new narrative dataset on announcements of fiscal austerity measures. Working Paper.

Gründler, K. \& Sauerhammer, S. (2018), 'Do expectations matter? Reassessing the effects of government spending on key macroeconomic variables in Germany', Applied Economics Letters pp. 1-6.

Leeper, E. M., Richter, A. W. \& Walker, T. B. (2012), 'Quantitative effects of fiscal foresight', American Economic Journal: Economic Policy 4(2), 115-144.

Leeper, E. M., Walker, T. B. \& Yang, S.-C. S. (2013), 'Fiscal foresight and information flows', Econometrica 81(3), 1115-1145.

Matheson, T. \& Pereira, J. (2016), Fiscal Multipliers for Brazil, International Monetary Fund.

Mendonça, D., Marçal, E. \& Holland, M. (2016), Is fiscal policy effective in Brazil? An empirical analysis. FGV São Paulo School of Economics Working Paper 433 CEMAP n. 09.

Mendonça, M. J., Medrano, L. A. \& Sachisda, A. (2009), Avaliando os efeitos da política fiscal no Brasil: resultados de um procedimento de identificação agnóstica. Texto para Discussão IPEA, n. 1377.

Mertens, K. \& Ravn, M. O. (2010), 'Measuring the impact of fiscal policy in the face of anticipation: a structural VAR approach', The Economic Journal 120(544), 393-413. 
Mertens, K. \& Ravn, M. O. (2012), 'Empirical evidence on the aggregate effects of anticipated and unanticipated US tax policy shocks', American Economic Journal: Economic Policy 4(2), 145-181.

Moura, G. V. (2015), 'Multiplicadores fiscais e investimento em infraestrutura', Revista Brasileira de Economia 69(1), 75-104.

Oreng, M. (2012), Estimando o impacto da política fiscal no Brasil: 2004 a 2011. Mimeo.

Peres, M. A. F. \& Ellery Junior, R. d. G. (2009), 'Efeitos dinâmicos dos choques fiscais do governo central no PIB do Brasil', Pesquisa e Planejamento Econômico 39(2), 159-206.

Perotti, R. (2011), Expectations and fiscal policy: an empirical investigation. Working Paper 19, Growth and Sustainability Policies for Europe.

Pires, M. C. d. C. (2014), 'Política fiscal e ciclos econômicos no Brasil', Economia Aplicada 18(1), 69-90.

Ramey, V. A. (2011), 'Identifying government spending shocks: it's all in the timing', The Quarterly Journal of Economics 126(1), 1-50.

Ramey, V. A. \& Shapiro, M. D. (1998), Costly capital reallocation and the effects of government spending, in 'Carnegie-Rochester Conference Series on Public Policy’, Vol. 48, Elsevier, pp. 145-194.

Ricco, G. (2015), A new identification of fiscal shocks based on the information flow. ECB Working Paper 1813.

Romer, C. D. \& Romer, D. H. (2004), 'A new measure of monetary shocks: derivation and implications', American Economic Review 94, 1055-1084.

Romer, C. D. \& Romer, D. H. (2010), 'The macroeconomic effects of tax changes: estimates based on a new measure of fiscal shocks', American Economic Review 100, 763-801. 


\section{Appendix A Evolution of Forecasts}

Figure A.1: Professional forecasts for GDP growth and primary balance
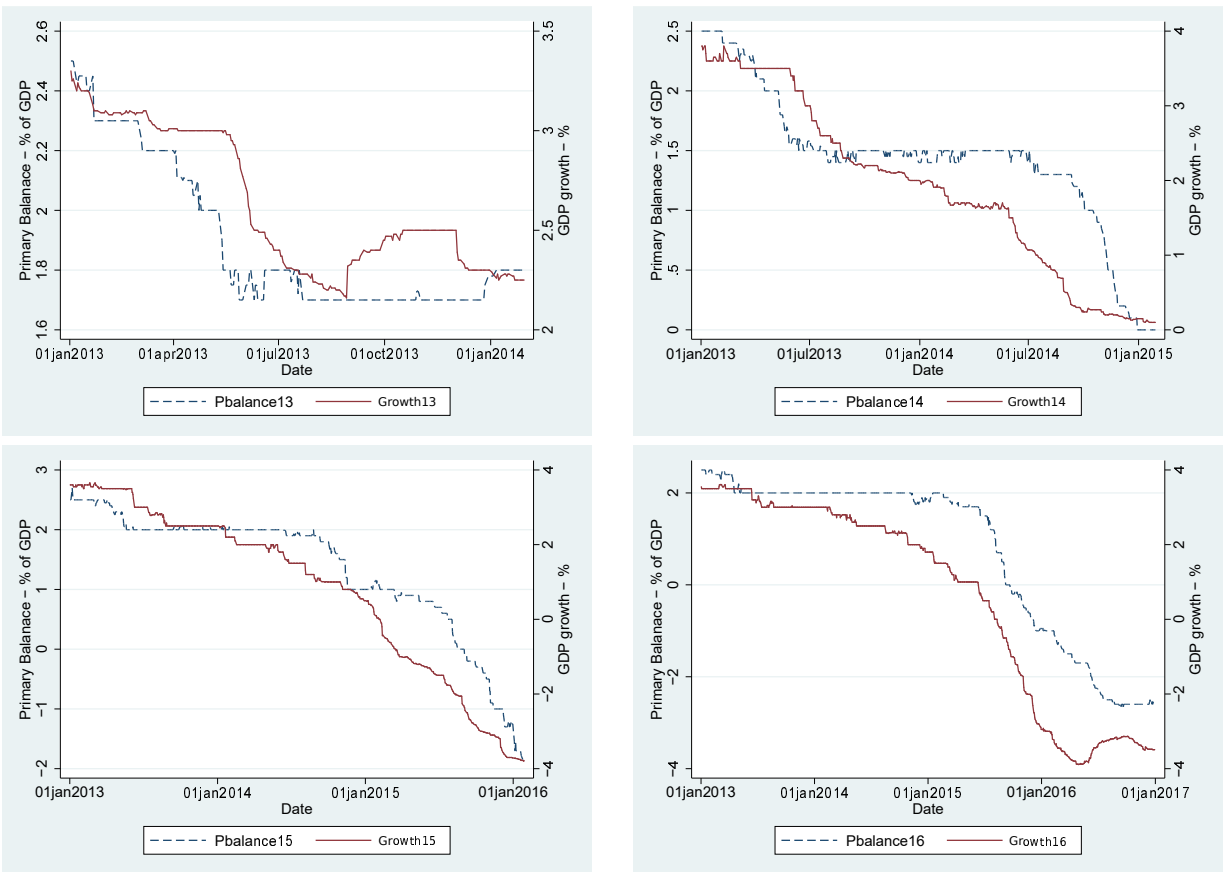


\section{Appendix B Granger Causality Tests}

Table B.1: Granger casuality tests

\begin{tabular}{llc}
\hline Year & Hypothesis Test & P-value in Parenthesis \\
\hline 2013 & $\begin{array}{l}\text { Do GDP growth forecasts Granger-cause pri- } \\
\text { mary balance forecasts? }\end{array}$ & No $(0,261)$ \\
2013 & $\begin{array}{l}\text { Do primary balance forecasts Granger-cause } \\
\text { GDP growth forecasts? }\end{array}$ & Yes $(0,004)$ \\
\hline 2014 & $\begin{array}{l}\text { Do GDP growth forecasts Granger-cause pri- } \\
\text { mary balance forecasts? }\end{array}$ & No $(0,748)$ \\
2014 & $\begin{array}{l}\text { Do primary balance forecasts Granger-cause } \\
\text { GDP growth forecasts? }\end{array}$ & No $(0,819)$ \\
\hline 2015 & $\begin{array}{l}\text { Do GDP growth forecasts Granger-cause pri- } \\
\text { mary balance forecasts? }\end{array}$ & No $(0,428)$ \\
2015 & $\begin{array}{l}\text { Do primary balance forecasts Granger-cause } \\
\text { GDP growth forecasts? }\end{array}$ & No $(0,553)$ \\
\hline 2016 & $\begin{array}{l}\text { Do GDP growth forecasts Granger-cause pri- } \\
\text { mary balance forecasts? }\end{array}$ & Yes $(0,001)$ \\
2016 & $\begin{array}{l}\text { Do primary balance forecasts Granger-cause } \\
\text { GDP growth forecasts? }\end{array}$ & Yes $(0,001)$ \\
\hline
\end{tabular}

Note: Results are based on bivariate VARs between each variables. Two lags were used for forecasts of 2014, three lags for forecasts for 2013 and 2016 and four lags for 2015.

\section{Appendix C Stability Tests}

The figures below show that all estimated VAR models are stable, with eigenvalues lying inside the unit circle. 
Figure C.1: Stability tests
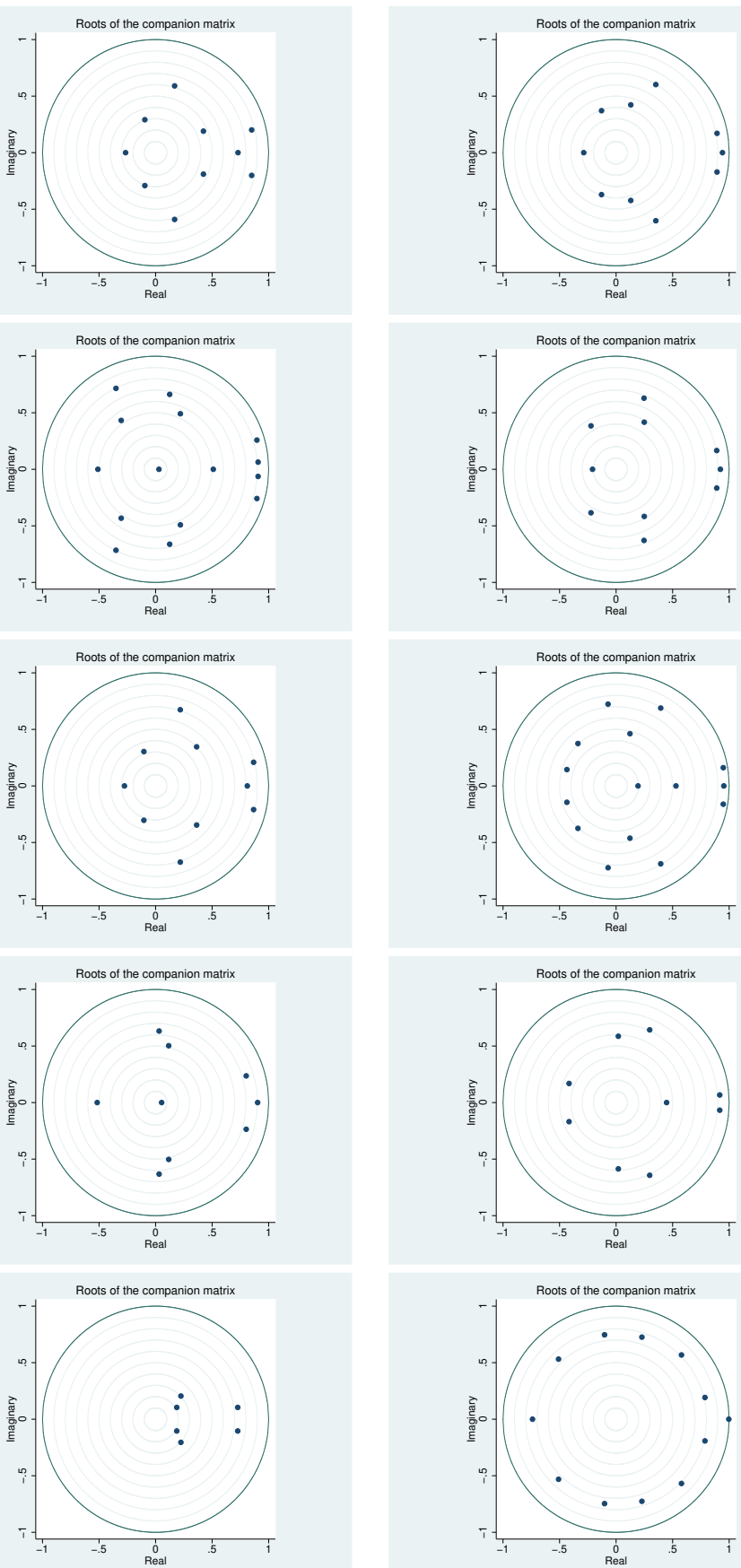


\section{Appendix D Historical Decomposition}

This section reports the historical decomposition of GDP growth from the baseline VAR in Section 5, including the following variables: unexpected fiscal news measure, GDP growth, inflation, real wage and the real exchange rate. Each panel in Figure D.1 shows the contribution of each endogenous variable to GDP growth in the model.
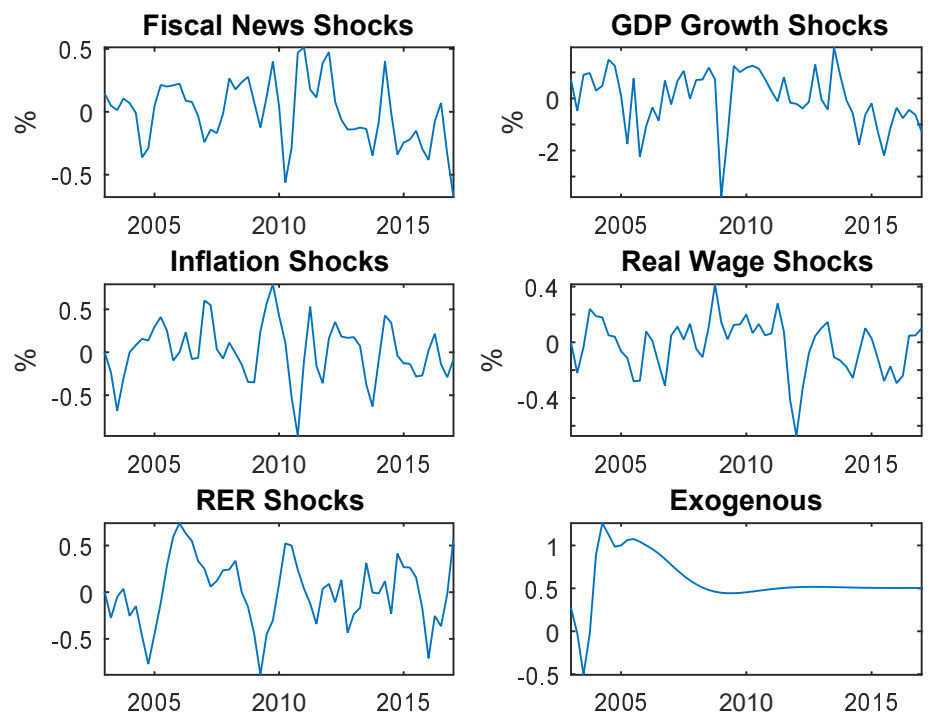

Figure D.1: Historical decomposition of GDP growth 


\section{Appendix E Impulse Responses}

This section reports the impulse responses with confidence intervals at $68 \%$ level. Fiscal tightening news give a temporary boost GDP growth through investment, as shown in the middle panel of the first row in Figure E.3. Despite this positive effect, consumer confidence and the expectations index decline after the shock. These effects are somehow difficult to reconcile with each other.

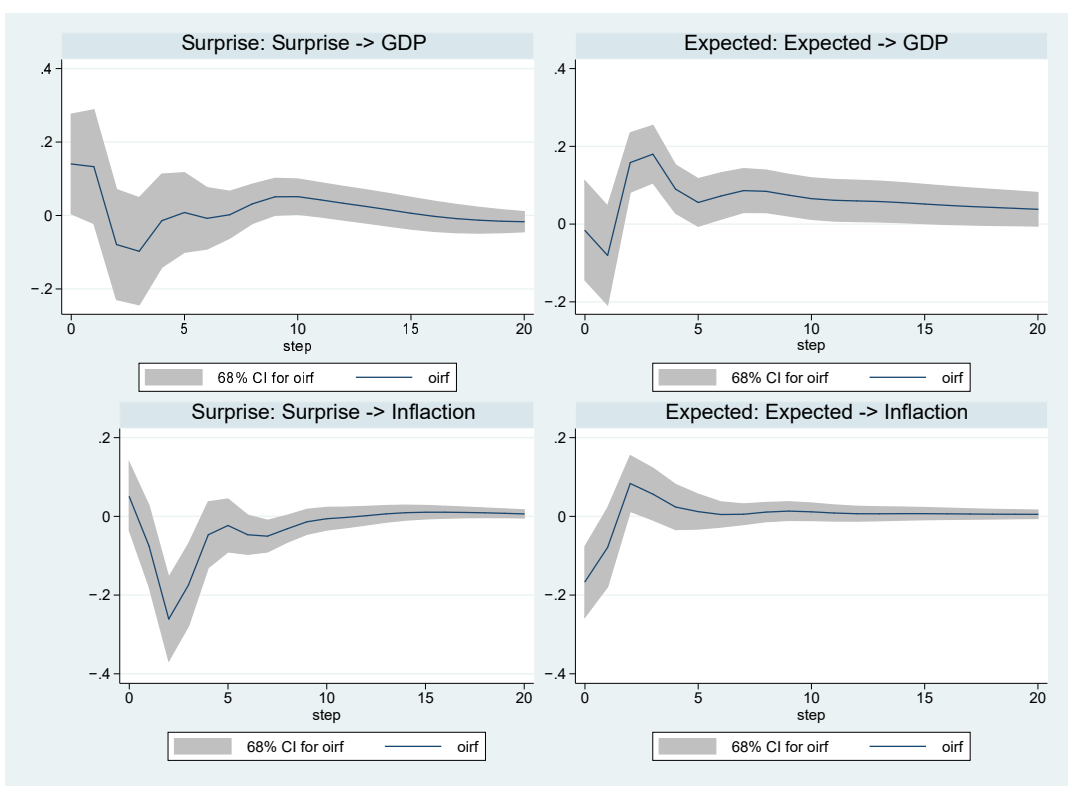

Figure E.1: Response of GDP and inflation to fiscal news shocks 


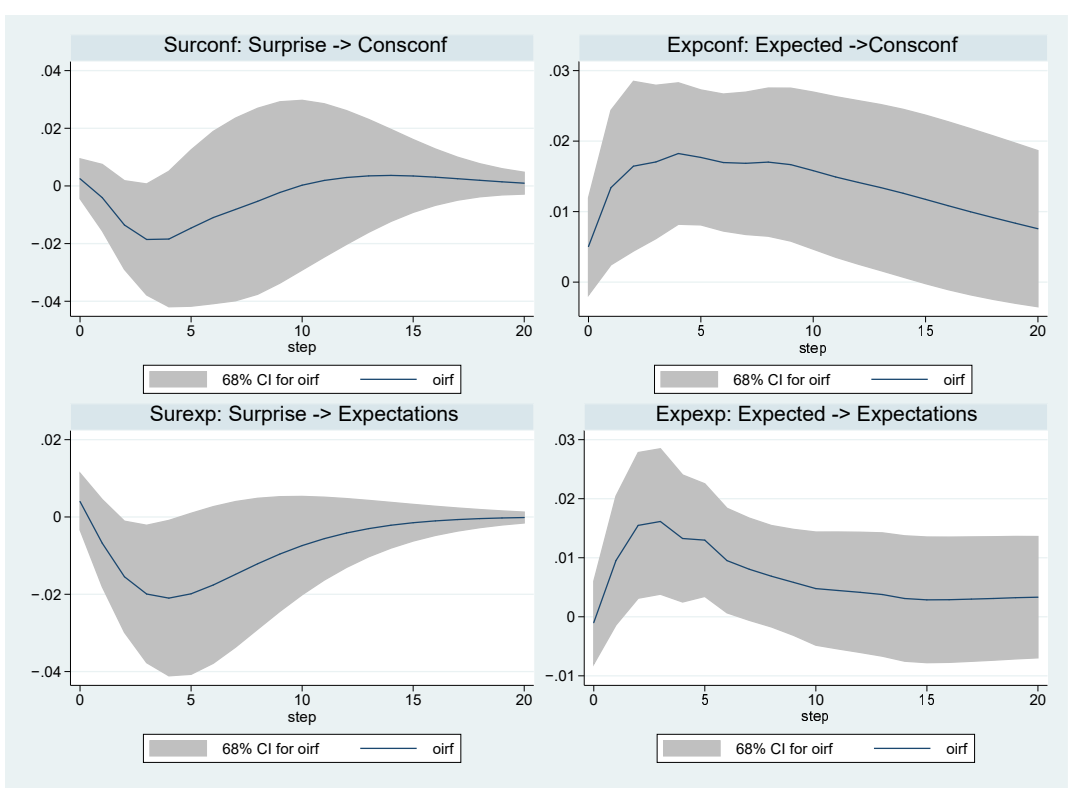

Figure E.2: Response of consumer confidence and expectations to fiscal news shocks

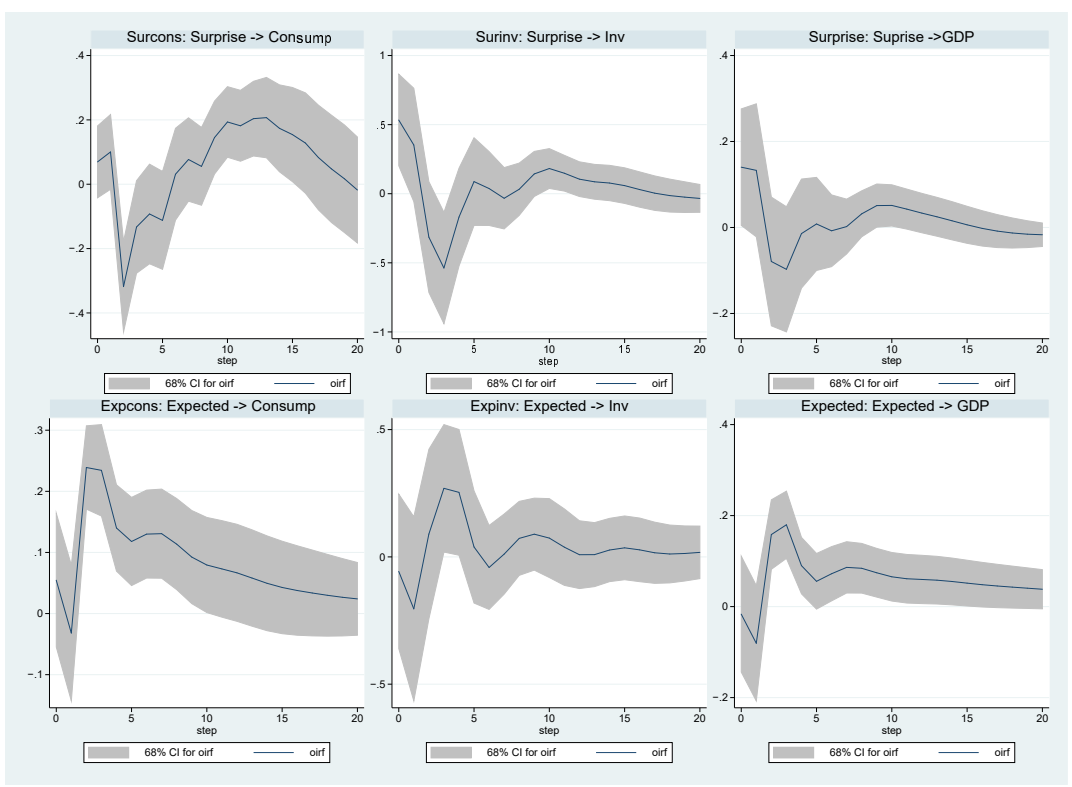

Figure E.3: Response of consumption, investment and GDP growth to fiscal news shocks 